\title{
ON A NEW SPECIES OF MELANOTAENIUM WITH A GENERAL ACCOUNT OF THE GENUS.
}

\author{
With Plate VIII. \\ By Rudolph Beer, B.Sc., F.L.S.
}

During the early summer of IgI 8 specimens of White Deadnettle (Lamium album) bearing curious tumour-like swellings caused by a fungus upon their underground organs were sent to the Pathological Laboratory at Kew. The diseased plants had been found by Mr W. F. Drew at Chalfont, Stroud, Gloucestershire, and upon request he kindly sent in I9I9 a further sample of plants from the same locality in rather an advanced state of disease.

There appears to be no other record of the occurrence of such intumescences upon Lamium album and a careful search both at Kew and elsewhere failed to discover any further examples of these tumours. It would appear, therefore, that the disease is a rare one and in spite of the small amount of material available for study it seems advisable to place the fact of its occurrence upon record and to give a brief description of its general characters and of the fungus causing it.

Description of New Species and its Systematic position.

As already mentioned the tumour-like swellings occur upon the subterranean parts of the plant (Pl. VIII, fig. I). In so far as the present material permits one to judge the intumescences are restricted to the underground stems and leaf-structures and are entirely absent from the roots and from the sub-aerial parts of the plant. In some cases they occur as dark blister-like swellings upon the side of the stem but when the entire circumference of the stem is affected they appear as distinct, spherical, tuberous bodies measuring as much as $8.5-9 \mathrm{~mm}$. in diameter. When a bud is attacked it becomes much swollen and its leaforgans greatly thickened and enlarged.

The presence of the disease does not cause the differentiation of any new structures in the organ but it stimulates the elements already present in the leaf or stem to division and growth. The swellings would, therefore, according to Küster's classification fall within the category of Kataplasmic galls*.

* Küster (1903) divides galls into two groups: (a) those which show little or no differentiation and are quite simple in their histological structure, and (b) those which exhibit specific differentiation and have quite a different histological structure from the normal organ. The former he names Kataplasmic galls, the latter Prosoplasmic galls. 
A section through one of the galls shows that a fungus is present and the general characters of this, with its large brown spores, evanescent mycelium and intercellular development, indicate that it is a member of the Ustilagineae.

As is well known the most important feature distinguishing the two groups into which this family is divided consists in their mode of spore germination. In the Ustilaginaceae the promycelium is divided by septa and the conidia are borne laterally whilst in the Tilletiaceae the conidia arise in a terminal whorl from the apex of the promycelium.

Unfortunately all attempts to bring about the germination of the spores of the present fungus in hanging drops have been unsuccessful so that dependence must be placed on other characters to determine whether the organism falls within the Ustilaginaceae or the Tilletiaceae.

It has been pointed out by Lutman (I9IO) in his paper on the "Life History and Cytology of the Smuts" that the two groups contrast with one another in the development of their haustoria. "The Ustilagos apparently get sufficient nourishment from their host plants by occupying intercellular spaces and perhaps by occasionally passing through a host cell. The smuts of the Tilletia group on the other hand have well developed haustoria in three species at least."

This character is by no means of universal application as several species of Ustilago, such for instance as U. Vaillantii Tul. described by Miss Massee (I9r4), have very well developed haustoria but taken together with the general features in the appearance and life-history of the fungus it lends weight to the view that the present fungus falls within the group of the Tilletiaceae.

Of the twelve genera of this group it appears to agree most nearly with Melanotaenium. The fact that the spores are simple and not bound together in balls and that they never lie loose upon the exterior of the plant but only reach the surface by the decay of the tissues of the host plant limits the number of genera to which the fungus may be relegated to three, viz.
Schinzia, Entyloma, and Melanotaenium.

In Schinzia (=Entorrhiza, Weber), which is a root parasite, the spores are pale to yellow-brown in colour with a membrane which is rough through the development of wart-like outgrowths. In the fungus at present under consideration the spores are dark brown and quite smooth. It is moreover not strictly a root parasite but appears (so far as the available material allows one to judge) to restrict its attacks to the subterranean stems andleaves. In Entyloma and Melanotaenium spore development and germination are very similar, the principal difference consisting in 
the distribution of the spores in the tissues of the host plant. In Entyloma the spore-masses are limited to small pustular swellings of the leaf or stem whilst in Melanotaenium the spores are spread over a wider area of the host tissues. In Entyloma, moreover, the spores germinate whilst they are still enclosed within the tissues of the host, whilst in Melanotaenium germination only takes place after the decay of these tissues.

In the case of the present fungus the spores are often spread over wide areas of the stem or leaf, whilst with regard to the question of their germination, although, as already mentioned, this has not been actually observed either in the tissues of the host plant or in artificial cultures, yet indirect evidence regarding the situation of their germination is obtained from the following experiments.

A series of inoculations were carried out on 15th May, I9I9, in which ungerminated spores derived from completely decayed intumescences were transferred to small wounds made in healthy plants by means of a sterilised scalpel.

Most of these were unsuccessful but in the case of one plant examined on the following September it was found that the characteristic swellings had developed upon the subterranean shoot in close proximity to the point of inoculation. The plant inoculated had been obtained from a district in which the disease was unknown and it was in all respects perfectly healthy. Care had been taken to ensure that the soil in which the plant was grown was uncontaminated.

From these observations it may be concluded that the spores of the fungus do not germinate whilst still within the tissues of the host but only after these tissues have decayed and favourable conditions for germination have been established. It will be seen, therefore, that in both the features which were mentioned above as distinguishing Melanotaenium from Entyloma the present fungus is in agreement with the former genus. The fungus is named and described upon a later page of the present paper (see p. 337).

\section{The Genus Melanotaenium.}

The genus Melanotaenium was established by de Bary (1874) who sorted out and rearranged the heterogeneous series of forms which had hitherto been grouped together under the names of Protomyces and Physoderma. Some he retained in these genera and others he referred to Entyloma, whilst one form, discovered by Unger (1833) and named by him Protomyces endogenus, he placed in a new genus, Melanotaenium, which he believed, quite correctly, to have its closest affinities with the Ustilagineae. $M$. endogenum is parasitic upon the stems and leaves of various 
species of Galium and causes the plants to become curiously dwarfed and blackened. It has a fairly wide distribution in this country having been found as far north as Aberdeenshire (Trail, 1884), whilst examples, preserved in the Kew Herbarium, have been collected at Swanage.

Protomyces Galii, Rabenhorst, described by Fuckel (I860) is apparently identical with Melanotaenium endogenum. Since this date the following species of Melanotaenium have been described: $M$. caulium Schroeter; $M$. cingens (Beck) Magnus; $M$. hypogaeum (Tul.) Schellenb.; $M$. Ari (Cooke) Lagerheim; $M$. Selaginellae Henn. et Nym.; $M$. Jaapii Magnus; and three doubtful species which have been named $M$. Sparganii Lagerh., $M$. maculare (Wallr.) Cornu, and $M$. scirpicolum Cornu.

With regard to the first of these (M. caulium) Schneider in I87I discovered a fungus growing parasitically upon Linaria vulgaris which in an unpublished communication he termed Ustilago caulium. In $188 \mathrm{r}$ Beck described a fungus upon the stems and leaves of Linaria genistifolia in the neighbourhood of Vienna. This he named Ustilago cingens.

De Toni in Saccardo's "Sylloge fungorum" (1888) included this fungus under the name Cintractia cingens. Schroeter (1889) in his "Kryptogamenflora von Schlesien" renamed Schneider"s fungus Melanotaenium caulium. Three years later Magnus (1892) found a fungus growing upon the stems of Linaria vulgaris at Bozen which agreed in its characters with the parasite originally discovered by Schneider and also with the one found by Beck upon $L$. genistifolia. As the result of his observations Magnus drew the conclusion that Ustilago caulium, U. cingens; Cintractia cingens and Melanotaenium caulium were all one species and suggested that this should be named Melanotaenium cingens (Beck) Magnus.

There is only a single record of the discovery of this fungus in the British. Isles. It was found in 1902 by $\mathrm{Mr}$ Theodore Green along the river Dee in the neighbourhood of Llangollen. Specimens of the British plant are preserved in the Kew Herbarium and at the British Museum.

Melanotaenium hypogaeum was first described by Tulasne (185I) as Ustilago hypogaea. It was found by him in tuberous swellings upon the hypocotyl and upper regions of the root of Linaria spuria. Since that time it has been found again by Dr John Lowe in I869 on the same host in the Isle of Wight as recorded by Phillips and Plowright (1884). It may be mentioned, however, that the specimen is not to be found in Plowright's herbarium. In I907, Cruchet again met with this fungus at Montagny. A brief account of the fungus was given by Fischer von Waldheim (I877) and again by Schellenberg (IgII) 
in the "Beiträge zur Kryptogamenflora der Schweiz," who transferred it to the genus Melanotaenium.

Melanotaenium Ari was first described by Cooke (1872) under the name of Protomyces Ari. It was found by Dr Paxton in May, I872, upon the leaves and petioles of Arum maculatum growing at Chichester. The same fungus was found in Denmark in 1876 by Rostrup who named it Ustilago plumbea. Thirteen years later Pirotta (I889) rediscovered this fungus growing upon the leaves of Biarum tenuifolium and, believing its affinities to be nearest to de Bary's genus Melanotaenium, he named it $M$. plumbeum (Rostr.) Pirotta. Rostrup in "Ustilagineae Daniae" (I890) accepted this nomenclature. Lagerheim (I899) found the fungus growing upon the leaves of Arum maculatum at Pardailhan and he referred to it under the name of Melanotaenium Ari (Cooke) Lagerheim. In more recent writings, such, for example, as "Danish Fungi," revised by J. Lind (rgr3) and Schellenberg's (I9II) "Beiträge zur Kryptogamenflora der Schweiz," and also in Jaap's "Fungi Selecti Exsiccata," issued by Magnus in I903, the name Melanotaenium Ari (Cooke) Lagerheim is retained. Through the kindness of Miss Wakefield and Mr J. Ramsbottom I have been enabled to re-examine Cooke's original type-material of this fungus as well as other specimens collected elsewhere at various times. I find the spores to be quite different in character from those of either Protomyces or of any member of the Ustilaginaceae. Their membrane is comparatively pale in colour and is more complex in structure than is the case with that of either of these groups. It consists of an inner layer (endospore) and a comparatively thick outer coat (exospore) which swells up vigorously in strong sulphuric acid. Moreover, the outer coat is perforated by several narrow germpores. It was not found possible to determine more nearly the details of the structure of this fungus or its spores in herbarium specimens, and the true systematic position of the fungus must be left undecided until fresh material becomes available.

$M$. Selaginellae Henn. et Nym. (Hennings Igoo) was found in Java growing upon the stem and bases of the leaves of Selaginella. Its spores are chestnut brown in colour and later black; their membrane is covered with wart-like outgrowths and they measure $\mathrm{I} 7-\mathrm{I} 9 \mu$ in diameter.

M. Jaapii Magn. was found by Jaap in IgII near Vienna growing upon Teucrium montanum, and a short description of this fungus was given by Magnus (I9II) in the same year. It forms swellings upon the base of the stem or the upper region of the root and in one case it was found to occur higher up the stem of the plant. In sections it could be seen that the hyphae of the fungus run in the intercellular spaces and send haustoria 
into the surrounding cells. The spores, which are formed intercalarily upon the hyphae, are dark brown and possess a thick, firm, smooth membrane. The mature spores measure about 22$23 \cdot 3 \mu$ across their longest diameter. Often they are completely spherical but at other times they may measure $23.3 \times 20.6 \mu$, $23.3 \times 19.2 \mu$, or even $22.3 \times 17.8 \mu$ across their longest and shortest diameters respectively.

Besides the species mentioned above there are three others which have provisionally been placed under Melanotaenium but probably belong elsewhere. Of these, one is M. Sparganii which grows upon the leaves of Sparganium and possesses spores measuring 10-16 $\times 9-10 \mu$ in diameter and which are yellow-brown in colour. It was first described by Lagerheim (I899) and is probably more correctly to be referred to the Chytridiaceae.

Another doubtful form is $M$. maculare (Wallr.) Cornu. This occurs within the epidermal cells of the leaves of Alisma ranunculoides var. repens, and was first described by Wallroth as Physoderma maculare and provisionally referred to Melanotaenium by Cornu (I883). It forms small black spots upon the leaf but produces no swelling or hypertrophy of the tissues. This is almost certainly not a Melanotaenium and Wallroth's original name may be retained for it.

A third form which has been dubiously included under Melanotaenium by Cornu (1883) is $M$. scirpicolum Cornu. This occurs upon the rhizome of Scirpus lacustris. Its spores are ovoid, pale brown in colour and measure $28-32 \times 18-20 \mu$ in diameter.

The foregoing appears to be a complete list of all the species of Melanotaenium which have hitherto been described and it remains to see what relationship the parasite upon Lamium album bears towards them.

$\begin{array}{ccc}\text { Species } & \text { Host } & \begin{array}{c}\text { Spore } \\ \text { measurement }\end{array} \\ \begin{array}{c}\text { M. cingens (Beck) Magnus } \\ \text { (Syn. M. caulium Schr) }\end{array} & \begin{array}{c}\text { Stems and leaves of Linaria } \\ \text { vulgaris and L. genistifolia }\end{array} & 12-18 \mu \\ \begin{array}{c}M \text {. hypogaeum (Tul.) Schel- } \\ \text { lenberg }\end{array} & \begin{array}{c}\text { Hypocotyl and root of Lina- } \\ \text { ria spuria }\end{array} & 14-22 \mu \\ M \text {. endogenum (Unger) de } & \begin{array}{c}\text { Stems and leaves of Galium } \\ \text { spp. }\end{array} & 16-22 \mu \\ \begin{array}{c}\text { Bary } \\ \text { (M. Ari (Cooke) Lagerheim }\end{array} & \begin{array}{c}\text { Leaves and petioles of Arum } \\ \text { maculatum }\end{array} & 14-16 \mu \text { ) } \\ M_{\text {. Selaginellae Henn. et }} & \begin{array}{c}\text { Stem and leal bases of Sela- } \\ \text { ginella }\end{array} & 17-19 \mu \\ M . \text { Jaapii Magnus } & \begin{array}{c}\text { Stem and root of Teucrium } \\ \text { montanum }\end{array} & 17 \cdot 8-23 \mu \\ M . \text { Lamii, sp. nov. } & \begin{array}{c}\text { Subterranean stems and buds } \\ \text { of Lamium album }\end{array} & 17-20 \mu\end{array}$

The points in which the species are differentiated from one another are very-slight and dependence has been chiefly placed 
upon the size of the spores and upon the host plant which they attack. Omitting the doubtful forms the most important facts regarding the known species are briefly summarised in the above table.

From what has been said above, it will be recognised how slight are the morphological features which distinguish the species of Melanotaenium from one another. No doubt a more complete knowledge of the germination, development and cytology of the different forms would reveal other characters which would differentiate them morphologically rather more sharply from one another. In the meanwhile we must admit the total inadequacy of the existing morphological criteria for this purpose.

The slight differences observed in the dimensions of the spores of the various forms may quite possibly be due, partly to dissimilar conditions under which development has taken place, and partly to the personal equation which inevitably enters into the case when a number of different observers measure a comparatively small number of selected spores with different instruments.

The conclusion to which these remarks trend is that in the Melanotaeniums, as indeed in the Smuts in general, the "species conception" can only be used as a convenient means of separating the several forms which occur upon different host plants. It can have here even less significance, as a hard and fast morphological distinction between natural entities, than is the case with the more highly differentiated organisms in which several investigators, such as Klebs, Goebel and Brierley, have shown that the various morphological characters are merely the expression of the interaction between two factors: the internal, molecular constitution of the protoplasm upon the one hand and the external environment upon the other, and that if either of these factors vary the morphological characters may become changed. Based upon its occurrence upon a new host plant, I therefore consider it advisable, provisionally at any rate, to regard the Melanotaenium which has been found upon Lamium album as a new species (in the above sense) and would suggest for it the name Melanotaenium Lamii sp. nov.

\section{Melanotaenium Lamir sp. nov.*}

The fungus forms intumescences or tuber-like swellings upon the subterranean stems and buds of Lamium album. Spore mass

* Melanotaenium Lamii sp. nov.

Sori atri; sporae globosae vel ovatae, I 7-20 $\mu$ diam., episporio crasso, glabro, atro-brunneo tectae, per matricis putrefactionem liberatae. Sporarum germinatio non visa. Sporae hyphaeque totam matricem penetrantes inter. cellulares, mycelium haustoriis praeditum. In caulibus gemmisque subterraneis Lamii albi, tubercula forma variis ad $8-9 \mathrm{~cm}$. diam. efficiens. 
black, liberated by the decay of the host tissue. Spores spherical to oval, measuring $17-20 \mu$ in diameter. Spore-membrane thick, smooth, dark brown. Germination of spores not observed. The spores and hyphae occur in the cortex and pith of the host plant and are also frequently found in vascular tissue. Hyphae forming pseudo-parenchymatous masses in the intercellular spaces of host. Host plant Lamium album. Found at Chalfont, Stroud, Gloucestershire, by Mr W. F. Drew.

\section{Morphology and Cytology of M. Lamii and comparison with other Genera.}

Such features in the morphology and cytology of the fungus as the small amount of the material available permitted to be ascertained will now be described. The hyphae of the fungus run between the cells of the host plant and at the intercellular spaces they often become massed, closely interwoven, and frequently septate so that they form a pseudo-parenchymatous body at these spots (fig. 2).

Haustoria are developed at numerous points and these penetrate the cell wall and form much branched, coralloid structures within the host cell (figs. 5 and I0). They usually attain a considerable size and form a conspicuous feature in the morphology of the fungus. They resemble a bunch of grapes in form, and are seen to consist of a series of very short branchlets which arise from the apex of a common carrying thread and each of which is dichotomously forked at its end (fig. 6). The main thread of the haustorium arises as an ordinary lateral branch from one of the intercellular hyphae. No appressorium could be seen such as Lutman (Igro) described in Entyloma Nymphaeae (Cunn.) Setch.

Lutman also found in his plant that the host cell nucleus frequently becomes enclosed in a tangled knot formed of the haustorial branches. In Melanotaenium Lamii the terminal branchlets of the haustorium have several times been observed to be closely applied to the nucleus of the host plant so that this body becomes partly enveloped by them (fig. 5) but this is not a constant feature, and just as many cases can be observed in which the haustorium and cell nucleus remain widely separated from one another (fig. Io) as those in which a closer relationship is established between them.

In spite of a number of works on the subject our knowledge of the cytology of the Ustilagineae is still very incomplete. Not only is the available information about any of the genera of this family contradictory but many genera have never been investigated at all. The genus Melanotaenium is among the latter and the few facts ascertained and described below may form the 
starting-point for a more complete account when more abundant material becomes available.

With regard to the nucleus of Ustilagineae the following is a summary of work already carried out. The earliest paper of importance is that by Dangeard (1892). He examined Ustilago Tragopogi, U. Carbo, U. violacea, Doassansia Alismatis, Entyloma Glaucii, Urocystis Violae, and Tilletia Caries, and found that the spore-bearing hyphae and the young spores are always bi-nucleate.

In I899 Harper (I899) confirmed Dangeard's results, working on Ustilago Carbo, U. Maydis, U. antherarum, and $U$. Scabiosae. Federley (I904) for the first time observed a passage of the nucleus from one conidium to the other during the conjugation of these bodies in Ustilago Tragopogonis-pratensis Pers. He believed that these nuclei fused at once and that a bi-nucleate stage of the hyphae and spores did not occur in this plant.

Six years later Lutman (1910) published the result of his investigations on Ustilago laevis, U. Zeae, Urocystis Anemones, Doassansia Alismatis and Entyloma Nymphaeae. He observed in Ustilago laevis that the conidia are uni-nucleate and that during conjugation the nucleus and most of the cytoplasm of one spore migrate into the other one. The mycelial cells in the host plant were found all to be bi- or multi-nucleate. During the development of the spores the two nuclei fuse so that the mature spore is uni-nucleate.

In IgI2 and I9I4 Rawitscher gave an account of the cytology of Ustilago Tragopogonis, U. Maydis and U. Carbo. In U. Tragopogonis-pratensis Pers. he found that the hyphae and young spores are bi-nucleate whilst the mature spore is uni-nucleate. The pro-mycelial cells and the conidia are uni-nucleate. In $U$. Maydis Corda the cells of the hyphae are uni-nucleate until just before spore-formation when the cell contents of two adjacent cells become fused with one another through the resorption of the membrane previously separating them from one another. Bi-nucleate spore rudiments are thus established. The two nuclei fuse and uni-nucleate spores result. The conidia are uni-nucleate.

In the case of $U$. Carbo it is either the cells of the uni-nucleate mycelium or the uni-nucleate sporidia themselves which may conjugate with one another and give rise to bi-nucleate cells. The young spores are bi-nucleate and the mature ones uninucleate.

In the case of Tilletia Tritici Rawitscher also found that the sporidia copulate in pairs and, upon their germination, give rise to bi-nucleate hyphae.

Werth and Ludwig (IgI2) came to very different conclusions 
in their examination of Ustilago antherarum Fr. They found neither a fusion of two nuclei in the spores nor the migration of one cell nucleus into the other cell during the anastomotic union between the two sporidia.

In I9I5 Wilson (1915) published a short account of his work upon the cytology of Tubercinia primulicola. He found the cells of the mycelium to be uni-nucleate, as are also the conidia which arise from it. The conidia conjugate in pairs and the nucleus of one passes through the connecting bridge into the other, giving rise to a bi-nucleate structure. The chlamydospores are formed in coils of hyphae which are bi-nucleate and which have most probably developed from the fusion-product of the two conjugating conidia. The spores are at first bi-nucleate but subsequently the two nuclei fuse and the mature spore is uni-nucleate.

Paravicini (1917) published an important contribution to the subject. He investigated the seven species into which the collective species $U$ stilago $C a r b o$ has now been divided as well as a number of other species including Tilletia Tritici (Bjerk.) Wint., Entyloma Calendulae (Oud.) de Bary, Urocystis Anemones (Pers.) Wint., and Urocystis Violae (Sow.) Fisch. v. Wald. In all cases he found the promycelial cells and the conidia to be uni-nucleate. Where the conidia conjugate with one another there is a passage of the nucleus from one spore to the other so that a bi-nucleate conidium results. In those cases, such as $U$. Tritici and $U$. nuda, in which no conidia are formed, the cells of the mycelium conjugate with one another and bi-nucleate cells are established by the migration of the nucleus from one cell to the other. The spores are bi-nucleate and the two nuclei fuse so that the mature spore is uni-nucleate.

No work has hitherto been done upon the cytology of the genus Melanotaenium. In the case of $M$. Lamii it was found to be a matter of considerable difficulty to ascertain the number of nuclei in the cells of the hyphae. These hyphae are usually exceedingly fine and their walls, especially the septa, stain very faintly with the dyes used. In the few favourable cases in which both the hyphal walls and the nuclei were satisfactorily stained two nuclei were present in each cell and it is most probable that this is the constant number in the cells of these hyphae (fig. 8). The young haustoria are filled with dense cytoplasm and contain two nuclei in each of the terminal branchlets, one lying in each fork of the branchlet. It was not possible to determine whether the branchlet is cut off from the main branch by a septum, but if this should prove to be the case we have here the bi-nucleate condition of the cells maintained in the haus-
torial apparatus. 
The spores are developed intercalarily upon the hyphae which form the pseudo-parenchymatous masses. The youngest spores observed measured ro $\times 6 \mu$ in diameter (fig. 4). Spores at this stage were seen to be unmistakably bi-nucleate and it was found that the bi-nucleate condition was maintained in the spore until quite shortly before maturity (fig. 7). The mature spore is uninucleate (figs. 8 and 9), presumably through the fusion of the two nuclei which exist during the earlier stages, but the actual fusion was not observed. The single nucleus of the later stages is, however, much larger in size than either of the nuclei which occur in the bi-nucleate stage and this probably indicates that it has arisen through the union of the two smaller nuclei.

It may be mentioned here that spores in the most various stages of development may occur close together within one pseudo-parenchymatous mass of hyphae. Thus in fig. 3 a mature spore containing a single nucleus occurs side by side with a much younger one which is still bi-nucleate.

The spore-membrane itself is apparently single and no success was obtained in attempting to demonstrate any lamination in it or in revealing the presence of an endospore in any of the spores which were examined*.

It will be seen from this brief account that the mature spore of Melanotaenium is uni-nucleate whilst the hyphal cells and the young spores are bi-nucleate. As germination of the spores of $M$. Lamii was not obtained it is not possible to say definitely where the transition between the uni-nucleate and the bi-nucleate stages occurs, but it may be pointed out that Woronin (188r) in his study of $M$. endogenum observed numerous cases of the germination of the spores and found the conidia conjugating with one another. It is not improbable that this is the point in the life history of the fungus at which, by the passage of the nucleus from one conidium to the other, it attains the bi-nucleate condition.

I should like here to express my great indebtedness to Miss Wakefield for her kind assistance throughout in the preparation of this paper.

\section{BIBLIOGRAPHY.}

de Bary, A.-Protomyces macrosporus u. seine Verwandten. (Bot. Zeit. Bd. XXXII, p. 105, 1874.)

Beck, G.-Plantae Novae. (Oesterreich Bot. Zeit. Bd. XXXI, p. 3I, 188I.)

Cooke, M. C. -British Fungi. (Grevillea, No. I, p. 7, I872.)

- Osner (rgr6) found that the spores of Ustilago striaeformis (West.) Niessl. possessed a double spore coat, a thick, dark exospore and a hyaline endospore. 
Cornu, M.-Sur quelques Ustilaginées nouvelles. (Ann. sci. nat. 1883, pp. 288 and 290.)

Dangeard, P. A.- Sur la Reproduction sexuelle des Champignons. (Le Botaniste, t. 3, pp. 240-28I, I892.)

- La Reproduction sexuelle de l'Entyloma Glaucii Dang. (Le Botaniste, t. 4, pp. I2-17, 1894.)

Federley, H.-Die Kopulation der Konidien bei Ustilago Tragopogonis-pratensis. (Finska Vetensk. Soc. Vorhandl. Heft 2, pp. I-23, I903-4.)

Fischer v. Waldheim, A.-Aperçu Systematique des Ustilaginées; p. I. Paris, 1877 .

Fuckel, L.-Enumeratio Fungorum Nassoviae, Series 1. p. I, I860.

Harper, R. A,-Nuclear Phenomena in certain stages in the Development of the Smuts. (Trans. Wiscons. Acad. Science, Part II. Pp. 475-498, I899.)

Hennings, P.-Monsunia, Bd. I. p. 2, rgoo.

Kuster, E.-Pathologische Pflanzenanatomie. Jena, I903.

Lagerheim, G.-Contributions à la Flore Mycologique des Environs de Montpellier. (Bull. Soc. Myc. Fr. Xv, pp. 9899, r899.)

Lind, J.-Danish Fungi as represented in the Herbarium of E. Rostrup, p. 27I. Copenhagen, IgI3.

Lutman, B. F.-Some Contributions to the Life History and Cytology of the Smuts. (Trans. Wiscons. Acad. Science, XVI, Part II. P. I223, I9I0.)

Magnus, P,-Beitrag zur Kenntniss einer oesterr. Ustilaginee. (Oesterr. Bot. Zeitschr. Bd. XIII, pp. 37-40, 1892.)

- Ein neues Melanotaenium aus Thüringen. (Ber. d. deutsch. bot. Ges. Bd, XxIx, pp. 456-458, IgII.)

Massee, I.-Observations on the Life History of Ustilago Vaillantii Tul. (Journ. Econ. Biol. Vol. Ix, pp. 5-I4, I9I4.)

Osner, G. A.-Leaf Smut of Timothy. (Cornell Univ. Agr. Exp. Sta. Bull. 38r, p. 202, I916.)

Paravicini, E.-Untersuchungen über das Verhalten der Zellkerne bei der Fortpflanzung der Brandpilze. (Ann. Myc. Vol. xv, pp. 57-96, x917.)

Phillips, W., and Plowright, C. B.-New and Rare British Fungi. (Grevillea, xIII, p. 52, $1884-5$.)

Pirotta, R.-Osservazioni sopra alcuni Funghi. (Nuovo Giorn. Bot. Ital. ser. I, XXI, pp. 3I2-313, I889.)

Rawitscher, F,-Beiträge zur Kenntniss der Ustilagineen. (Zeitschr. f. Bot. Bd. Xv, 1v. pp. 673-706, 1912.)

- Zur Sexualität der Brandpilze, Tilletia Tritici. (Ber. d. deutsch. bot. Ges. pp. 310-314, I9I4.) 
Trans. Brit. Myc. Socy.

Vol. VI., PI. VI]
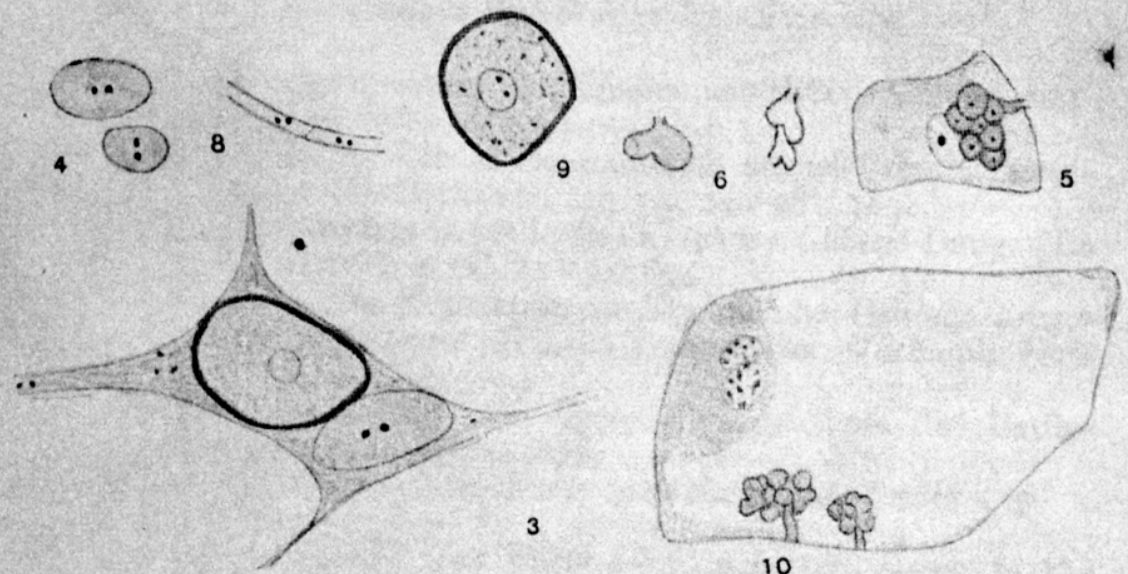

3
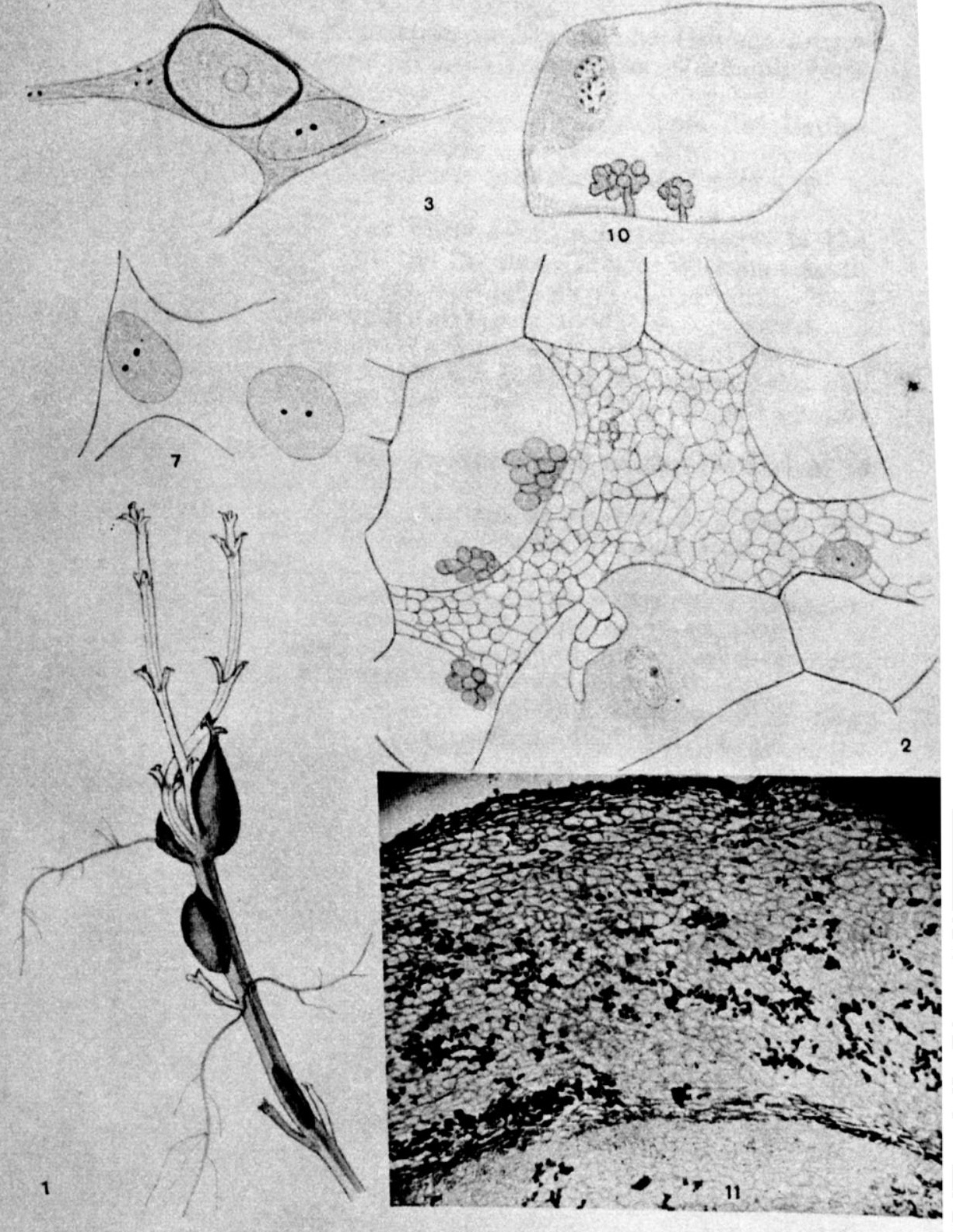

R. Beer del. 
On a New Species of Melanotaenium. Rudolph Beer. 343

Rostrup, E-Ustilagineae Daniae. (Bot. Forenings Festskrift Kjobenhavn, pp. II7-I68, I890.)

Schellenberg, H. C.-Die Brandpilze der Schweiz, Bd. III. Heft 2, p. I08, IgrI.

Schroeter, J-Kryptogamenflora von Schlesien, III, I; Ustilaginei, pp. 26I-29r, 1889 .

Trail, J. W. H.-Two New British Ustilagineae. (Scott. Nat. VI, new ser. p. 243, 1884.)

Tulasne, L. R.-Fungi Hypogeae, p. I96. Paris, I\$5I.

Unger, F.-Die Exanthema der Pflanzen, I 333 .

Wilson, M.-The Life History and Cytology of Tubercinia primulicola Rost. (Brit. Assoc. Reports, Sect. K, I9 15.)

Werth, E., and Ludwig, R.-Zur Sporenbildung bei Rost u. Brandpilze. (Ber. d. deutsch. bot. Ges. Bd. xxx, I9I2.)

Woronin, M.-Beitrag zur Kenntniss der Ustilagineen. (Abhandl. d. Senk. naturf. Ges. Frankfort, Bd. XIi, pp. 583584, I88r.)

Fig.

\section{EXPLANATION OF PI.ATE VIII}

I. Rhizome of Lamium album with swellings caused by $M e-$ lanotaenium Lamii.

2. Mycelium forming pseudo-parenchymatous mass in an intercellular space of host plant. $\times 1000$.

3. Spores of M. Lamii; one young, the other mature. $\times 1000$.

4. Very young spores of $M$. Lamii. × 1000 .

5. Haustorium of $M{ }^{\circ}$ 'Lamii, partly enveloping host nucleus. $\times$ I000.

6. Dichotomously branched terminal branchlets of haustorium. $\times 1000$.

7. Young bi-nucleate spores of $M$. Lamii. $\times 1000$.

8. Bi-nucleate hypha of $M$. Lamii. × Iooo.

9. Mature uni-nucleate spore of M. Lamii. $\times$ Iooo.

Io. Two haustoria of $M$. Lamii within a bi-nucleate cell of host plant. $\times 1000$.

II. Section of an intumescence upon a subterranean stem of Lamium album showing distribution of the spores of $M$. Lamii within its tissues. From a microphotograph. 